Vaillancourt, R. E., B. M. Potts, A. Manson, T. Eldridge and J. B. REID (1995): Using RAPDs to detect QTLs in an interspecific $\mathrm{F}_{2}$ hybrid of Eucalyptus. pp 430-433. In: Potts, B. M., Borralho, N. M. G., Reid, J. B., Cromer, R. N., TibBits, W. N. and RAYMOND, C. A. (eds) Eucalypt plantations: Improving fibre yield and quality. Proceedings papers CRC IUFRO conference, Hobart, Australia.

VAN OOIJEN, J. W. and R. E. VoORRIPS (2001): Joinmap ${ }^{\circledR}$ 3.0, software for the calculation of genetic linkage maps. Plant Research International, Wageningen, the Netherlands.

Verhaegen, D. and C. Plomion (1996): Genetic mapping in Eucalyptus urophylla and Eucalyptus grandis using RAPD markers. Genome 39: 1051-1061.

VOLKER, P. W. (2002): Genetics of Eucalyptus globulus, E. nitens and $\mathrm{F}_{1}$ hybrid. $\mathrm{PhD}$ Thesis, University of Tasmania, Australia.
Vos, P., R. Hogers, M. Bleeker, M. Reijans, T. Van DE Lee, M. Hornes, A. Frijters, J. Pot, J. Peleman, M. KUIPER and M. ZABEAU (1995): AFLP: a new technique for DNA fingerprinting. Nucleic Acids Research 23: 4407-4414.

WiLliAMs, E. R. and D. WHITAKER (2001): Outmap ${ }^{\odot} 1.0$, a package for genetic mapping, CSIRO forestry and forest products, Canberra, Australia and University of Waikato, Hamilton, New Zealand.

Wu, R. L., Y. F. Han, J. J. Hu, J. J. FANG, L. Li, M. L. Li and Z. B. ZENG (2001): An integrated genetic map of Populus deltoides based on amplified fragment length polymorphisms. Theoretical \& Applied Genetics 100: 1249-1256.

\title{
Genetic Variation and Correlations between Growth and Wood Density of Calycophyllum spruceanum at an Early Age in the Peruvian Amazon
}

\author{
By C. Sotelo Montes ${ }^{1), *}$, R. E. Hernández ${ }^{1)}$, J. Beaulieu ${ }^{2)}$ and J. C. WebeR ${ }^{3)}$
}

(Received $17^{\text {th }}$ February 2006)

\begin{abstract}
Calycophyllum spruceanum (Benth.) Hook. f. ex K. Shum. is an important timber-tree species in the Peruvian Amazon Basin. As farmers and industry often use wood from young trees, it is important to investigate variation in juvenile wood properties in this species. A provenance/progeny test was established to evaluate genetic variation in growth and wood properties of young trees, the strength of their genetic control as well as their interrelationships both at the genetic and the phenotypic level in different planting zones. In this paper, results are presented for tree height and stem diameter (near ground level) at 16, 28 and 39 months; and stem diameter and basic density of the wood at breast height at 39 months. Significant variation due to provenances and especially due to families within provenances was found in growth and wood density. Phenotypic and genetic correlations indicated that larger trees tended to have denser wood. Wood density had higher heritability than height and diameter; and genetic con-
\end{abstract}

1) Centre de recherche sur le bois, Pavillon Gene Kruger, Université Laval, Québec (Québec), G1K7P4, Canada.

2) Natural Resources Canada, Canadian Forest Service, Fibre Centre, 1055 du P.E.P.S., P.O. Box 10380, Stn. Sainte-Foy, Quebec, Quebec, G1V4C7, Canada.

${ }^{3}$ ) World Agroforestry Centre (ICRAF), B.P. 320, Bamako, Mali; and Adjunct Professor, Faculty of Forestry and Geomatics, Laval University.

*) Author for correspondence: Telephone: 418-656-5852, fax: 418656-2091. E-mail: soteloc@hotmail.com trol over height, diameter and density was generally highest in the planting zone where trees grew most rapidly.

Key words: provenance, family, environment, heritability, phenotypic and genetic correlations, juvenile wood.

\section{Introduction}

The Peruvian Amazon has many valuable timber-tree species, but there has been little research on genetic variation in these species. Farmers and industry commonly use juvenile wood, and they will probably use it even more in the future with the promotion of agroforestry and small-scale plantation forestry. Tree breeders, therefore, should initiate research on genetic variation in properties of juvenile wood to see whether it is possible to improve them through breeding work and to measure the impact of selection for juvenile wood traits on other traits (ZoBEL and SPRAGUE, 1998).

Calycophyllum spruceanum (Benth.) Hook. f. ex K. Shum. (Rubiaceae family) is a pioneer species that colonizes the floodplain and disturbed forests in the Amazon Basin (LINARES et al., 1992). The breeding system has not been studied, but is assumed to be primarily outcrossing like the majority of tropical trees (BAWA et al., 1990). Trees have hermaphroditic flowers, and mature in 2 to 3 years in open-grown conditions. There is probably extensive gene flow, producing high levels of genetic variation within populations and relatively low genetic 
differentiation among populations (RUSSELL et al., 1999).

Farmers rank C. spruceanum as a priority for lumber, poles, firewood and charcoal in agroforestry systems in the Peruvian Amazon (Sotelo Montes and WeBer, 1997). Adult trees (age unknown) in natural stands can attain heights of $35 \mathrm{~m}$ with stem diameters of $1.8 \mathrm{~m}$ at breast height (SEARS, 2003). The wood is diffuse-porous, with a basic density of $740 \mathrm{~kg} / \mathrm{m}^{3}$ for mature wood (age unknown) in natural stands (measured at $1.3 \mathrm{~m}$ above ground; KEENAN and TEJADA, 1984) and $563 \mathrm{~kg} / \mathrm{m}^{3}$ at 32 months of age in plantations (measured from 35 to 65 $\mathrm{cm}$ above ground, Weber and Sotelo Montes, 2005). It is generally assumed that mature wood is formed after 15-20 years in natural stands, but this has not been confirmed by studies. Stems can be harvested for construction poles after 2 to 3 years, or sawn timber after 15 to 20 years, and then coppiced for successive harvests. The wood has demand in national and international markets for furniture, wall paneling and parquet (TOLEDO and RINCÓN, 1996).

Tree growth and wood density are known to be influenced by both genetic and environmental factors (ZOBEL and JeTt, 1995; Zobel and Sprague, 1998). The first provenance test of $C$. spruceanum established in Peru demonstrated that plantation yield could be increased by selecting fast-growing provenances (SOTELO MONTES et al., 2003; Weber and Sotelo Montes, 2005). However, phenotypic correlations between growth and wood density differed in sign among planting zones, suggesting that selection of fast-growing provenances may produce wood with lower density in some zones and higher density in other zones.

Heritability estimates are needed to assess the potential genetic gain that can be realized by selection, and estimates of genetic correlations are necessary to assess if selection based on growth significantly affects wood density. Since heritabilities and genetic correlations depend on the specific test environment and population of trees (FALCONER and MACKAY, 1996), they should be evaluated in contrasting environments and in different populations. In general, wood density has a higher heritability than growth traits, and the genetic correlation between growth and density is low for diffuse-porous hardwoods (ZOBEL and JETT, 1995).

This paper presents results from a provenance/progeny test of C. spruceanum in the Peruvian Amazon Basin. The objectives of this paper were to (a) determine the relative magnitude of variation in tree growth and wood basic density at an early age that is due to provenances and families, (b) evaluate phenotypic and genetic correlations between these traits, and the heritability of these traits in different planting zones. Tree growth was measured at 16, 28 and 39 months, while wood density was measured at 39 months. The major results are compared with other tropical hardwoods, and some practical implications are discussed.

\section{Materials and Methods}

\section{Sample region and study area}

The sample region is located in the Aguaytía watershed of the Peruvian Amazon (Figure 1). Large natural stands of $C$. spruceanum occur along the rivers in the lower, middle and upper parts of the watershed, and on upland soils in the upper part of the watershed; whereas smaller stands occur on upland soils in the lower and middle parts of the watershed. Trees are also scattered throughout most of the watershed, so it is assumed that the stands are not genetically isolated and are subpopulations of the same genetic population. Moreover, it is assumed that some inbreeding has occurred and continues to occur in these subpopulations.

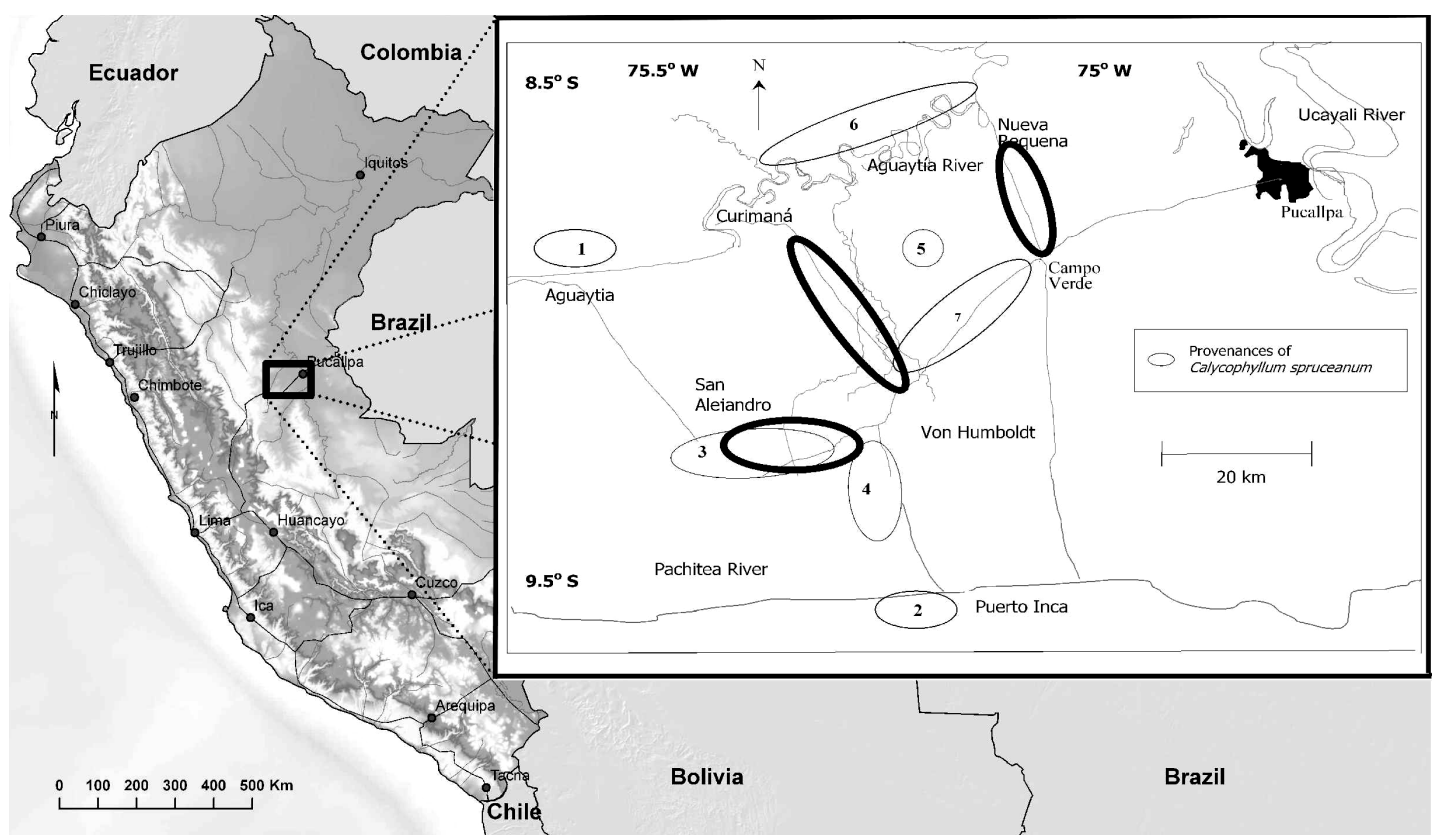

Figure 1. - Geographic location of the sample region and study area in the Aguaytía watershed of the Peruvian Amazon: inset shows the location of the seven provenances of Calycophyllum spruceanum and the three planting zones (bold circles). 
Table 1. - Site details for the provenance/progeny test of Calycophyllum spruceanum established in the lower, middle and upper zones of the Aguaytía watershed in the Peruvian Amazon. ${ }^{\mathrm{a}, \mathrm{b}}$

\begin{tabular}{|c|c|c|c|}
\hline $\begin{array}{l}\text { Location in the } \\
\text { watershed }\end{array}$ & $\begin{array}{l}\text { Altitude } \\
\text { (masl) }\end{array}$ & $\begin{array}{l}\text { Rainfall } \\
(\mathrm{mm} / \mathrm{yr})\end{array}$ & Soil texture, acidity and available cations (Ultisols) \\
\hline Lower zone & 150 & 1400 & $\begin{array}{l}\text { - Sandy } \\
\text { - Very acidic (pH } 4 \text { to } 4.5,20 \text { to } 50 \% \text { aluminum saturation) } \\
\text { of levels of available phosphorous, and intermediate levels } \\
\text { of potassium, calcium and magnesium }\end{array}$ \\
\hline Middle zone & 180 & 1750 & $\begin{array}{l}\text { - Heavy with clay } \\
\text { - Very acidic (pH } 4 \text { to } 4.5,20 \text { to } 50 \% \text { aluminum saturation) } \\
\text { of potassium, calcium and magnesium, }\end{array}$ \\
\hline Upper zone & 240 & 2500 & $\begin{array}{l}\text { - Light with organic matter } \\
\text { - Slightly acidic (pH } 6 \text { to } 6.5 \text { ) } \\
\text { - High levels of available phosphorous, potassium, calcium and } \\
\text { magnesium }\end{array}$ \\
\hline
\end{tabular}

Open-pollinated seeds were collected in SeptemberOctober 1998 from 200 mother trees of C. spruceanum growing in seven natural stands located in the lower, middle and upper parts of the Aguaytía watershed (Figure 1). The stands are referred to hereafter as provenances, using this term in the broad sense as the source of seed (MORGENSTERN, 1996). Farmers selected the trees that had good bole form and no external diseases. To reduce the chance of sampling siblings, at least $100 \mathrm{~m}$ was maintained between any two selected trees. Selection intensity was only about $20 \%$, so there is probably little difference between the selected trees and the entire population in each provenance. The number of selected trees $(13,20,47,47,10,47$ and 16 for provenance codes 1 to 7 , respectively) was roughly proportional to the total number in each provenance.

The provenance/progeny test was established in the lower, middle and upper parts of the Aguaytía watershed (hereafter called planting zones), but restricted to upland, non-alluvial soils (Figure 1). In this region, June through September is a dry season, which is most severe in the lower zone and least severe in the upper zone. General information about rainfall and soils of the study area is given in Table 1.

\section{Experimental design and management of the provenance / progeny test}

Seedlings of the 200 families were grown in a nursery for 15 months and then transplanted into the experimental sites in February 2000. The experimental design was a randomized complete block (RCB): five replications were established on different farms in each of the lower, middle and upper zones of the watershed. In each replication, the 200 families were randomly assigned to 200 experimental plots. Experimental plots consisted of two trees of the same family. Spacing was 2.5 by 2.5 meters within and between rows. Two rows of border trees surrounded the experimental design on each site. Dead trees were replaced during the first dry season, but data collected on replants were not included in the analyses.
Management practices included establishment of a cover crop, application of fertilizer, branch pruning, manual weeding and a selective thinning. Centrosema macrocarpum Benth., a leguminous herb, was sown between rows and $5 \mathrm{~m}$ around the perimeter of each replication to control soil erosion, moderate soil surface temperature, improve soil fertility, reduce weed invasion, and provide farmers with a cash crop (seed for pastures). Organic compost (1 kg) and rock phosphate (200 g) were placed in each planting hole, and inorganic nitrogen, phosphorous and potassium (70 g N, $185 \mathrm{~g} \mathrm{P}$, and $100 \mathrm{~g} \mathrm{~K}$ ) were applied around each tree 22 and 34 months after planting. Branches were pruned from the lower half of the stem 18 months after planting. One tree in each experimental plot was thinned 39 months after planting. This was a selective thinning mainly based on tree form (primarily stem bifurcations in the canopy) and growth. Farmers weeded their replications approximately every 4 weeks during the rainy season, and every $6-8$ weeks during the dry season. They could do this in 2-3 days when they had available time and labor, but it took much longer during periods of peak demand on their time and labor pool. As a result, weeding was not systematically done.

The provenance/progeny test had both research and development objectives (WEBER et al., 2001), and this required some compromises in the experimental design. Farmers wanted to evaluate all 200 families in their replications, in order to select the best families and transform their replications into seed orchards. The RCB design was selected in response to this development objective. An incomplete block design with fewer families per replication would have been more efficient experimentally (STEEL et al., 1997), but it would not have satisfied the farmers' objective. The relatively large replication size (around $0.3 \mathrm{ha}$ ) combined with farmers' weeding practices (SOTELO MonTES et al., 2003) could have affected the differences among families within replications as well as the stability of families across replications. 


\section{Traits measured in the provenance/progeny test}

Tree height and stem diameter $(10 \mathrm{~cm}$ above ground) were measured on both trees in each experimental plot in all 15 replications at 16, 28 and 39 months. Height was measured to the nearest $\mathrm{cm}$ using a meter stick or telescopic measuring pole. Diameter was measured to the nearest $0.1 \mathrm{~cm}$ using callipers or diameter tape.

Stem diameter at breast height (Dbh) and basic density of the wood (1.3 $\mathrm{m}$ above ground) were measured on the thinned trees in nine replications (three in each planting zone) at 39 months. The other six replications (two in each planting zone) were excluded because mean diameter of the trees was too small to provide enough samples for analysis of wood density. Moreover, wood density was not analyzed for all trees in the nine replications due to the small Dbh of many trees, especially in the lower zone, as well as tree mortality. Dbh was measured to the nearest $0.1 \mathrm{~cm}$. For wood density, one disk (10 cm thick) was taken from each tree, and stored at $4^{\circ} \mathrm{C}$ for 4 months. A 2 -cm thick disk was then cut from the larger disk, the bark was removed, and the disk was soaked in distilled water for 48 hours. Disks with large knots or any damage were excluded. Then basic density (oven-dry mass to green volume, $\mathrm{kg} / \mathrm{m}^{3}$ ) was determined using the water-displacement method (ASTM, 1997).

Although the thinned trees were not randomly selected from the two trees in each experimental plot, it is unlikely that this would affect the general conclusions about the relative magnitude of variation in wood density due to provenances and families within provenances, and the correlations between growth and wood density. There are four reasons to support this assumption. (1) Wood density was not used as a selection criterion in the thinning. (2) Means for height and diameter at $10 \mathrm{~cm}$ above ground $(6.95 \mathrm{~m}$ and $9.24 \mathrm{~cm}$, respectively) of the thinned trees were essentially the same as the means for all trees in the nine replications $(6.83 \mathrm{~m}$ and $9.16 \mathrm{~cm}$, respectively). Therefore, we would expect that the mean density of the thinned trees would be similar to that of all trees in the nine replications. The coefficients of variation were slightly lower for the thinned trees (36\% versus $42 \%$ ). (3) Analysis of variance of height and diameter of the thinned trees (using the model for analysis across zones presented in the next section) produced essentially the same results as the analysis of variance of all trees in the nine replications, and all trees in the test. This indicates that the thinned trees were a representative sample, in terms of height and diameter, of all trees in the test. (4) The frequency of trees with forks in the canopy was slightly higher among the thinned trees, compared with all trees in the nine replications $(24 \%$ versus $19 \%$ ). However, it is unlikely that this slight increase in the incidence of forks would produce any significant bias in wood density, in particular because wood was sampled from the stem below the canopy.

\section{Statistical analyses}

The SAS $^{\circledR}$ statistical package, version 8 (SAS INSTITUTE INC., 1999), was used for all statistical analyses. Departure from the normal distribution and homogeneity of variance were tested for the residuals using statis- tics provided by the UNIVARIATE procedure. Data transformations were not considered necessary to satisfy the assumptions of analysis of variance and other analyses.

Analyses of variance were carried out using the GLM procedure with the Type III (partial sums of squares) estimation method to assess the relative magnitude of each source of variation. Analyses were performed across zones, and separately within each planting zone. The objective of the within-zone analyses was to determine if the relative magnitude of variation due to genetic factors was similar in planting zones with different environmental conditions. Variation in height and diameter (10 $\mathrm{cm}$ above ground) was assessed at each age (16, 28 and 39 months), while variation in Dbh and basic density was assessed at 39 months only. Variance of height and diameter across zones was analyzed according to a mixed linear model with the following sources of variation: zone, replication within zone [Rep(Zone)], provenance (Prov), family within provenance [Fam(Prov)], and the interactions [Prov*Zone, Prov*Rep(Zone), Fam(Prov)*Zone, Fam(Prov)*Rep (Zone)]. Variance of Dbh and basic density across zones was analyzed with a similar model, but the interaction between family and replication did not appear in the model because only one tree per plot was assessed. Models for the analyses within zones were similar to those used across zones, except that there was no source of variation due to zone and, therefore, no interactions with zones. Zone was fixed and all other factors were random. Some F-ratios involved more than one mean square in the denominator ("quasi" F-ratios), and were tested with approximate degrees of freedom.

Individual tree heritability $\left(h_{i}^{2}\right)$ was estimated only for traits for which variation among families was found to be significant at $\alpha \leq 0.05$ in the appropriate analyses of variance. The additive genetic variance was estimated as $3 \sigma_{\mathrm{f}}^{2}$ because, despite the sampling strategy used, we expected partial inbreeding in the populations. The terms in the denominator of $h_{i}^{2}$ depended on the model for the analysis of variance: Fam(Prov), Fam(Prov)* Zone, Fam(Prov)*Rep(Zone) and residual variation for tree height and diameter (10 $\mathrm{cm}$ above ground) across zones; Fam(Prov), Fam(Prov)*Rep and residual variation for tree height and diameter within zones; Fam(Prov), Fam(Prov)*Zone and residual variation for Dbh and basic density across zones; Fam(Prov) and residual variation for $\mathrm{Dbh}$ and basic density within zones. Standard errors for $h_{i}^{2}$ were calculated using the formula provided by BECKER (1984).

Phenotypic and genetic correlations were calculated between growth traits and wood density across zones and within each zone. Correlations were assessed within zones to determine whether they were stable in different environmental conditions. Phenotypic correlations, i.e. Pearson correlation coefficients, were based on values for individual trees and were estimated using the CORR procedure. Genetic correlations were estimated only among traits for which variation among families was found to be significant at $\alpha \leq 0.05$. In order to eliminate the effect of different measurement scales when estimating genetic correlations, trait values were standardized 
Table 2. - Descriptive statistics of tree height and stem diameter (10 cm above ground) at 16, 28 and 39 months; and stem diameter at breast height (Dbh) and wood basic density at 39 months for Calycophyllum spruceanum. Statistics are given for all trees across zones, and separately for trees in the lower, middle and upper zones of the watershed. a,b $^{\mathrm{a}}$

\begin{tabular}{|c|c|c|c|c|c|c|c|c|c|c|c|c|}
\hline \multirow[t]{2}{*}{ Trait } & \multicolumn{3}{|c|}{ A. Across zones } & \multicolumn{3}{|c|}{ B. Lower zone } & \multicolumn{3}{|c|}{ C. Middle zone } & \multicolumn{3}{|c|}{ D. Upper zone } \\
\hline & Mean & $\mathrm{CV}$ & Range & Mean & $\mathrm{CV}$ & Range & Mean & $\mathrm{CV}$ & Range & Mean & $\mathrm{CV}$ & Range \\
\hline \multicolumn{13}{|l|}{ Height (m) } \\
\hline 16 months & 3.10 & 38.9 & 6.60 & 2.21 & 38.0 & 4.81 & 3.74 & 35.5 & 6.60 & 3.71 & 24.6 & 6.07 \\
\hline 28 months & 4.85 & 46.2 & 10.52 & 2.78 & 42.9 & 6.15 & 5.20 & 36.8 & 9.27 & 6.68 & 22.2 & 10.23 \\
\hline 39 months & 6.23 & 47.3 & 12.25 & 3.29 & 42.5 & 7.30 & 6.69 & 36.3 & 11.77 & 8.64 & 21.6 & 11.34 \\
\hline \multicolumn{13}{|l|}{ Diameter $(\mathrm{cm})-10 \mathrm{~cm}$ above ground } \\
\hline 16 months & 4.89 & 36.1 & 9.60 & 3.67 & 35.9 & 8.65 & 5.37 & 33.1 & 9.35 & 5.75 & 24.6 & 9.15 \\
\hline 28 months & 6.97 & 44.0 & 14.20 & 4.12 & 39.5 & 9.80 & 7.49 & 33.9 & 12.90 & 9.43 & 22.5 & 13.60 \\
\hline 39 months & 8.43 & 44.8 & 18.60 & 4.84 & 41.6 & 11.50 & 8.97 & 34.1 & 18.10 & 11.37 & 23.6 & 17.30 \\
\hline Dbh $(\mathrm{cm})-39$ months & 6.08 & 40.8 & 10.50 & 3.29 & 33.9 & 5.00 & 6.40 & 30.4 & 9.30 & 7.66 & 25.5 & 10.36 \\
\hline Basic density $\left(\mathrm{kg} / \mathrm{m}^{3}\right)-39$ months & 581.5 & 8.0 & 306.0 & 552.7 & 7.4 & 270.0 & 599.6 & 7.1 & 241.0 & 585.1 & 7.5 & 285.0 \\
\hline
\end{tabular}

a $\mathrm{CV}=$ coefficient of variation.

${ }^{\mathrm{b}}$ Number of trees. Across zones: height and diameter = 5360, 5278 and 4999 at 16, 28 and 39 months, respectively; Dbh = 1263; density = 1231. Lower zone: height and diameter = 1902, 1824 and 1664 at 16, 28 and 39 months, respectively; Dbh = 328; density $=326$. Middle zone: height and diameter $=1700,1695$ and 1606 at 16, 28 and 39 months, respectively; Dbh = 436; density $=422$. Upper zone: height and diameter = 1758, 1759 and 1729 at 16, 28 and 39 months, respectively; Dbh $=499$; density $=483$.

Table 3. - Analysis of variance of tree height and stem diameter (10 cm above ground) at 16, 18 and 39 months for Calycophyllum spruceanum. Analyses are given for all trees across zones, and separately for trees in the lower, middle and upper zones of the watershed. ${ }^{\mathrm{a}, \mathrm{b}}$

\begin{tabular}{|c|c|c|c|c|c|c|c|c|c|c|c|c|c|}
\hline \multirow[t]{3}{*}{ Source of variation } & \multirow[b]{3}{*}{ DF } & \multicolumn{6}{|c|}{ Height } & \multicolumn{6}{|c|}{ Diameter } \\
\hline & & \multicolumn{2}{|c|}{16 months } & \multicolumn{2}{|c|}{28 months } & \multicolumn{2}{|c|}{39 months } & \multicolumn{2}{|c|}{16 months } & \multicolumn{2}{|c|}{28 months } & \multicolumn{2}{|c|}{39 months } \\
\hline & & $\mathrm{P}>\mathrm{F}$ & VAR & $P>F$ & VAR & $\mathrm{P}>\mathrm{F}$ & $\overline{\text { VAR }}$ & $P>F$ & VAR & $\mathrm{P}>\mathrm{F}$ & VAR & $\mathrm{P}>\mathrm{F}$ & VAR \\
\hline Zone & 2 & 0.010 & $\overline{----}$ & $<0.001$ & --- & $<0.001$ & --- & 0.014 & --- & $<0.001$ & --- & $<0.001$ & $\overline{---}$ \\
\hline Prov & 6 & $<0.001$ & 3.1 & $<0.001$ & 2.9 & $<0.001$ & 2.2 & $<0.001$ & 1.9 & $<0.001$ & 2.6 & $<0.001$ & 2.3 \\
\hline Fam(Prov) & 193 & $<0.001$ & 7.7 & $<0.001$ & 8.1 & $<0.001$ & 8.2 & $<0.001$ & 4.9 & $<0.001$ & 6.8 & $<0.001$ & 6.6 \\
\hline Prov*Zone & 12 & 0.299 & 0.1 & 0.222 & 0.3 & 0.188 & 0.4 & 0.981 & 0.0 & 0.220 & 0.2 & 0.319 & 0.1 \\
\hline Prov*Rep(Zone) & 72 & 0.424 & 0.0 & 0.187 & 0.0 & 0.336 & 0.0 & 0.134 & 0.1 & 0.179 & 0.1 & 0.399 & 0.0 \\
\hline Fam(Prov)*Zone & 386 & 0.189 & 0.9 & 0.094 & 1.1 & 0.394 & 0.3 & 0.127 & 0.7 & 0.232 & 0.4 & 0.121 & 1.2 \\
\hline Residual & 2431 & --- & 56.0 & --- & 53.5 & --- & 58.4 & --- & 60.1 & --- & 64.7 & --- & 65.8 \\
\hline Total & 5359 & & & & & & & & & & & & \\
\hline
\end{tabular}

\begin{tabular}{|c|c|c|c|c|c|c|c|c|c|c|c|c|c|}
\hline \multirow[t]{3}{*}{ Source of variation } & \multirow[b]{3}{*}{ DF } & \multicolumn{6}{|c|}{ Height } & \multicolumn{6}{|c|}{ Diameter } \\
\hline & & \multicolumn{2}{|c|}{16 months } & \multicolumn{2}{|c|}{28 months } & \multicolumn{2}{|c|}{39 months } & \multicolumn{2}{|c|}{16 months } & \multicolumn{2}{|c|}{28 months } & \multicolumn{2}{|c|}{39 months } \\
\hline & & $\mathrm{P}>\mathrm{F}$ & VAR & $\mathrm{P}>\mathrm{F}$ & VAR & $\mathrm{P}>\mathrm{F}$ & VAR & & DF & $\mathrm{P}>\mathrm{F}$ & VAR & $\mathrm{P}>\mathrm{F}$ & VAR \\
\hline Rep & 4 & $<0.001$ & -- & $<0.001$ & -- & $<0.001$ & --- & $<0.001$ & -- & $<0.001$ & -- & $<0.001$ & -- \\
\hline Prov & 6 & 0.003 & 2.8 & 0.011 & 2.6 & 0.014 & 2.3 & 0.060 & 1.3 & 0.034 & 1.6 & 0.030 & 1.8 \\
\hline Fam(Prov) & 193 & 0.039 & 3.4 & 0.019 & 3.7 & 0.214 & 1.7 & 0.034 & 3.4 & 0.020 & 3.9 & 0.072 & 3.1 \\
\hline Prov*Rep & 24 & 0.115 & 0.7 & 0.024 & 1.7 & 0.062 & 1.8 & 0.016 & 1.8 & 0.012 & 2.0 & 0.029 & 2.1 \\
\hline Fam(Prov)*Rep & 766 & $<0.001$ & 46.6 & $<0.001$ & 46.7 & $<0.001$ & 46.0 & $<0.001$ & 44.4 & $<0.001$ & 45.8 & $<0.001$ & 46.1 \\
\hline Residual & 908 & --- & 46.5 & -- & 45.3 & --- & 48.2 & -- & 49.1 & --- & 46.7 & -- & 46.9 \\
\hline Total & 1901 & & & & & & & & & & & & \\
\hline
\end{tabular}

\begin{tabular}{|c|c|c|c|c|c|c|c|c|c|c|c|c|c|}
\hline \multicolumn{14}{|l|}{ C. Middle zone } \\
\hline \multirow[t]{3}{*}{ Source of variation } & \multirow[b]{3}{*}{ DF } & \multicolumn{6}{|c|}{ Height } & \multicolumn{6}{|c|}{ Diameter } \\
\hline & & \multicolumn{2}{|c|}{16 months } & \multicolumn{2}{|c|}{28 months } & \multicolumn{2}{|c|}{39 months } & \multicolumn{2}{|c|}{16 months } & \multicolumn{2}{|c|}{28 months } & \multicolumn{2}{|c|}{39 months } \\
\hline & & $\mathrm{P}>\mathrm{F}$ & VAR & $P>F$ & VAR & $\mathrm{P}>\mathrm{F}$ & VAR & & DF & $\mathrm{P}>\mathrm{F}$ & VAR & $P>F$ & VAR \\
\hline Rep & 4 & $<0.001$ & --- & $<0.001$ & --- & $<0.001$ & --- & $<0.001$ & $\overline{---}$ & $<0.001$ & $\overline{---}$ & $<0.001$ & $-\overline{-}$ \\
\hline Prov & 6 & $<0.001$ & 4.5 & $<0.001$ & 4.0 & 0.001 & 3.4 & 0.002 & 2.4 & $<0.001$ & 3.7 & $<0.001$ & 3.1 \\
\hline Fam(Prov) & 193 & $<0.001$ & 9.0 & $<0.001$ & 9.9 & $<0.001$ & 10.0 & $<0.001$ & 5.3 & $<0.001$ & 6.9 & $<0.001$ & 7.7 \\
\hline Prov*Rep & 24 & 0.537 & 0.0 & 0.479 & 0.0 & 0.620 & 0.0 & 0.476 & 0.2 & 0.349 & 0.2 & 0.520 & 0.0 \\
\hline Fam(Prov)*Rep & 736 & $<0.001$ & 28.7 & $<0.001$ & 30.1 & $<0.001$ & 31.3 & $<0.001$ & 29.9 & $<0.001$ & 25.4 & $<0.001$ & 25.7 \\
\hline Residual & 736 & --- & 57.8 & --- & 56.0 & --- & 55.3 & --- & 62.2 & --- & 63.8 & --- & 63.5 \\
\hline Total & 1699 & & & & & & & & & & & & \\
\hline
\end{tabular}

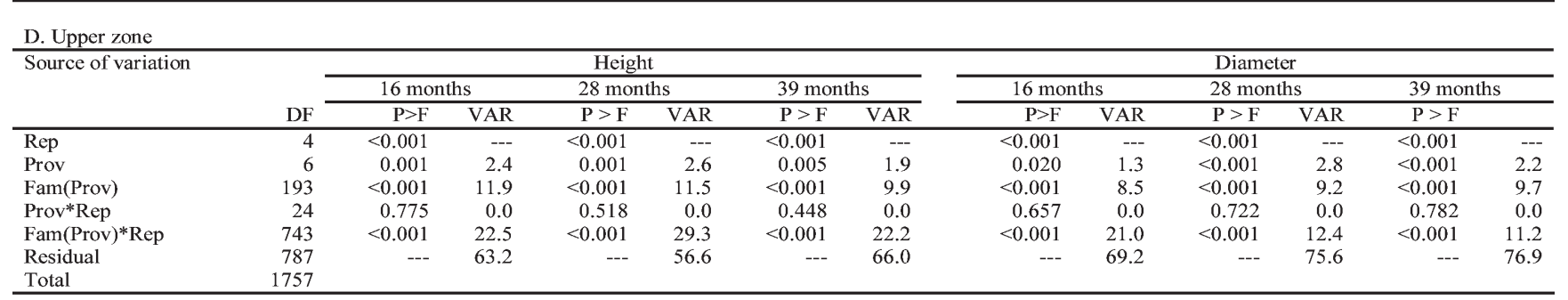

${ }^{\mathrm{a}} \mathrm{DF}=$ degrees of freedom. $\mathrm{P}>\mathrm{F}=$ significance of $\mathrm{F}$ ratio. $\mathrm{VAR}=$ percentage of the total phenotypic variance explained by the variance component.

${ }^{\mathrm{b}}$ Due to mortality, DF decreases over time. At 39 months, DF is 2151 for Fam(Prov)*Rep(Zone) and 2164 for Residual in analysis across zones; 705 for Fam(Prov)*Rep and 731 for Residual in the lower, 712 for Fam(Prov)*Rep and 666 for Residual in the middle, and 734 for Fam(Prov)*Rep and 767 for Residual in the upper zone of the watershed. 
$($ mean $=0$, standard deviation $=1 ;$ STEEL et al., 1997) for calculations across zones and within each zone. Variance components were estimated using the VARCOMP procedure with the restricted maximum likelihood method. Covariance components for variables $\mathrm{x}$ and $\mathrm{y}$ were obtained by solving the equation $\sigma^{2}{ }_{\mathrm{fxy}}=\left(\sigma_{\mathrm{f}(\mathrm{x}+\mathrm{y})}^{2}-\sigma_{\mathrm{fx}}^{2}-\right.$ $\left.\sigma_{\mathrm{fy}}^{2}\right) / 2$. Approximate standard errors of genetic correlations were calculated using the formula provided by FALCONER and MACKAY (1996).

\section{Results}

Judging from the coefficients of variation (CV), there was considerable variation in growth among all trees in the test, and relatively more variation in Dbh than in basic density of the wood (Table 2). Moreover, there was relatively more variation in tree growth in the lower and middle zones than in the upper zone of the watershed.

Table 4. - Analysis of variance of stem diameter at breast height (Dbh) and wood basic density at 39 months for Calycophyllum spruceanum. Analyses are given for all trees across zones, and separately for trees in the lower, middle and upper zones of the watershed. ${ }^{\mathrm{a}}$

\begin{tabular}{lrrrrrrr} 
A. Across zones & \multicolumn{1}{c}{ Dbh } & & \multicolumn{3}{c}{ Density } \\
\cline { 2 - 5 } \cline { 6 - 8 } Source of variation & DF & P>F & VAR & & DF & P $>$ F & VAR \\
\hline Zone & 2 & 0.002 & --- & & 2 & 0.067 & --- \\
Rep(Zone) & 6 & $<0.001$ & --- & & 60.001 & --- \\
Prov & 6 & 0.002 & 3.6 & & 6 & $<0.001$ & 6.0 \\
Fam(Prov) & 193 & $<0.001$ & 10.0 & & 193 & $<0.001$ & 17.7 \\
Prov*Zone & 12 & 0.017 & 0.2 & & 12 & 0.945 & 0.0 \\
Prov*Rep(Zone) & 36 & 0.997 & 0.0 & & 36 & 0.601 & 0.0 \\
Fam(Prov)*Zone & 355 & 0.985 & 0.0 & & 353 & 0.314 & 1.2 \\
Residual & 652 & --- & 86.2 & & 622 & --- & 81.1 \\
Total & 1262 & & & & 1230 & & \\
\hline
\end{tabular}

B. Lower zone

\begin{tabular}{lrrrrrr}
\hline Source of variation & \multicolumn{3}{c}{ Dbh } & \multicolumn{3}{c}{ Density } \\
\cline { 2 - 7 } & DF & P>F & VAR & DF & P>F & VAR \\
\hline Rep & 2 & $<0.001$ & --- & 2 & 0.002 & --- \\
Prov & 6 & 0.002 & 4.5 & 6 & 0.027 & 5.3 \\
Fam(Prov) & 170 & 0.346 & 6.1 & 169 & 0.024 & 15.1 \\
Prov*Rep & 12 & 0.994 & 0.0 & 12 & 0.637 & 0.0 \\
Residual & 137 & --- & 89.4 & 136 & --- & 79.6 \\
Total & 327 & & & 325 & & \\
\hline
\end{tabular}

\begin{tabular}{|c|c|c|c|c|c|c|}
\hline \multirow[t]{2}{*}{ Source of variation } & \multicolumn{3}{|c|}{ Dbh } & \multicolumn{3}{|c|}{ Density } \\
\hline & $\mathrm{DF}$ & $\mathrm{P}>\mathrm{F}$ & VAR & DF & $\mathrm{P}>\mathrm{F}$ & VAR \\
\hline Rep & 2 & $<0.001$ & --- & 2 & $<0.001$ & --- \\
\hline Prov & 6 & 0.028 & 3.7 & 6 & 0.009 & 5.5 \\
\hline Fam(Prov) & 188 & 0.094 & 7.3 & 187 & $<0.001$ & 19.1 \\
\hline Prov*Rep & 12 & 0.621 & 0.0 & 12 & 0.436 & 0.0 \\
\hline Residual & 227 & --- & 89.0 & 214 & --- & 75.4 \\
\hline Total & 435 & & & 421 & & \\
\hline
\end{tabular}

\begin{tabular}{|c|c|c|c|c|c|c|}
\hline \multirow[t]{2}{*}{ Source of variation } & \multicolumn{3}{|c|}{ Dbh } & \multicolumn{3}{|c|}{ Density } \\
\hline & $\mathrm{DF}$ & $\mathrm{P}>\mathrm{F}$ & VAR & DF & $\mathrm{P}>\mathrm{F}$ & VAR \\
\hline Rep & 2 & $<0.001$ & --- & 2 & $<0.001$ & $\overline{---}$ \\
\hline Prov & 6 & $<0.001$ & 4.7 & 6 & 0.003 & 5.3 \\
\hline Fam(Prov) & 190 & 0.045 & 8.7 & 190 & $<0.001$ & 18.8 \\
\hline Prov*Rep & 12 & 0.976 & 0.0 & 12 & 0.491 & 0.4 \\
\hline Residual & 288 & --- & 86.6 & 272 & --- & 75.5 \\
\hline Total & 498 & & & 482 & & \\
\hline
\end{tabular}

${ }^{\mathrm{a}} \mathrm{DF}=$ degrees of freedom. $\mathrm{P}>\mathrm{F}=$ significance of $\mathrm{F}$ ratio. VAR $=$ percentage of the total phenotypic variance explained by the variance component.
For example, CVs for tree height at 39 months were approximately $42 \%, 36 \%$ and $22 \%$ in the lower, middle and upper zones. CVs were inversely related to mean growth in the zones.

The minimum mean density was observed in the zone of slowest tree growth whereas the highest value was in the zone of intermediate growth (lower and middle zones, respectively). The difference between these zones was $8 \%$ of the overall mean.

Overall tree mortality was $16.7 \%$ at 39 months. It varied by about $6 \%$ among planting zones and provenances, and $40 \%$ among families. It was fairly evenly distributed across plots in each replication, so inter-tree competition was similar among plots. Mortality was not analyzed as a trait, but it must be considered when the best performing families are selected and the replications are transformed into seed orchards.

Variation in tree height and stem diameter (10 cm above ground) at 16, 28 and 39 months

Differences in height and diameter among zones and variation due to replications within zones were significant at all ages in the analysis of variance across zones (Table 3). Variation due to provenances and families within provenances was also significant at all ages. Families accounted for slightly more variation than provenances but together accounted for only 7 to $11 \%$ of the total phenotypic variance (VAR). Judging from the interactions, the relative differences in mean height and diameter among provenances and families were relatively stable across zones. Similarly, provenance means were relatively stable across replications within zones, but significant variation was created by the interaction between families and replications within zones.

Analyses of variance within zones generally led to the same conclusions as the analyses across zones. There was significant variation in height and diameter due to replications, provenances and families (except at 39 months in the lower zone), and the interaction between replications and families; whereas variation due to the interaction between replications and provenances generally was not significant. VAR due to provenances was very low in all zones, and VAR due to families was highest in the upper zone.

\section{Variation in Dbh and basic density of wood at 39 months}

There were significant differences in Dbh, but not in wood density, among planting zones (Table 4). However, variation due to replications within zones, provenances and families within provenances was significant for both Dbh and density in the analysis across zones. Families accounted for a larger percentage of the total phenotypic variance (VAR) than provenances, and families accounted for a larger percentage in density than in Dbh. Provenance rankings in density were very stable across zones, judging from the non-significant interaction between provenance and zone. However, the variation due to the interaction between provenances and zones was significant for Dbh.

Analyses within zones gave some contrasting results regarding variation due to provenances and families. 
Variation due to provenances and families within provenances was significant for density in all three zones. Variation due to provenances was also significant for Dbh in all three zones, but variation due to families within provenances was significant only in the upper zone.
Estimates of individual tree heritability $\left(h_{i}^{2}\right)$ and correlations between tree growth and basic density of wood

Some trends were observed in the $h_{i}^{2}$ of tree height and stem diameter (10 $\mathrm{cm}$ above ground) (Table 5). Height generally had higher $h_{i}^{2}$ than diameter at all ages. The $h_{i}^{2}$ of both height and diameter were usually

Table 5. - Heritability of tree height and stem diameter (10 $\mathrm{cm}$ above ground) at 16, 28 and 39 months; and stem diameter at breast height (Dbh) and wood basic density at 39 months for Calycophyllum spruceanum. Heritability is given for all trees across zones, and separately for trees in the lower, middle and upper zones of the watershed. The standard error is given in parentheses, followed by the number of trees involved in the calculation. ${ }^{\mathrm{a}}$

\begin{tabular}{|c|c|c|c|c|}
\hline Trait & Across zones & Lower zone & Middle zone & Upper zone \\
\hline \multicolumn{5}{|l|}{ Height (m) } \\
\hline 16 months & $\begin{array}{r}0.24(0.04) \\
5360\end{array}$ & $\begin{array}{r}0.10(0.06) \\
1902\end{array}$ & $\begin{array}{r}0.28(0.08) \\
1700\end{array}$ & $\begin{array}{r}0.37(0.09) \\
1758\end{array}$ \\
\hline 28 months & $\begin{array}{r}0.25(0.05) \\
5278\end{array}$ & $\begin{array}{r}0.11(0.06) \\
1824\end{array}$ & $\begin{array}{r}0.31(0.08) \\
1695\end{array}$ & $\begin{array}{r}0.35(0.08) \\
1759\end{array}$ \\
\hline 39 months & $\begin{array}{r}0.25(0.05) \\
4999\end{array}$ & NSF & $\begin{array}{r}0.31(0.09) \\
1606\end{array}$ & $\begin{array}{r}0.30(0.08) \\
1729\end{array}$ \\
\hline $\begin{array}{l}\text { Diameter }(\mathrm{cm}) \\
10 \mathrm{~cm} \text { above ground } \\
16 \text { months }\end{array}$ & $\begin{array}{r}0.15(0.03) \\
5360\end{array}$ & $\begin{array}{r}0.11(0.06) \\
1902\end{array}$ & $\begin{array}{r}0.16(0.07) \\
1700\end{array}$ & $\begin{array}{r}0.26(0.08) \\
1758\end{array}$ \\
\hline 28 months & $\begin{array}{r}0.21(0.04) \\
5278\end{array}$ & $\begin{array}{r}0.12(0.06) \\
1824\end{array}$ & $\begin{array}{r}0.22(0.08) \\
1695\end{array}$ & $\begin{array}{r}0.28(0.08) \\
1759\end{array}$ \\
\hline 39 months & $\begin{array}{r}0.20(0.04) \\
4999\end{array}$ & NSF & $\begin{array}{r}0.24(0.08) \\
1606\end{array}$ & $\begin{array}{r}0.30(0.08) \\
1729\end{array}$ \\
\hline $\begin{array}{l}\text { Dbh }(\mathrm{cm}) \\
39 \text { months }\end{array}$ & $\begin{array}{r}0.31(0.10) \\
1263\end{array}$ & $\mathrm{NSF}$ & $\mathrm{NSF}$ & $\begin{array}{r}0.27(0.21) \\
499\end{array}$ \\
\hline $\begin{array}{l}\text { Basic density }\left(\mathrm{kg} / \mathrm{m}^{3}\right) \\
39 \text { months }\end{array}$ & $\begin{array}{r}0.53(0.12) \\
1231\end{array}$ & $\begin{array}{r}0.48(0.32) \\
326\end{array}$ & $\begin{array}{r}0.61(0.25) \\
422\end{array}$ & $\begin{array}{r}0.60(0.22) \\
483\end{array}$ \\
\hline
\end{tabular}

${ }^{a} \mathrm{NSF}=$ Family within provenance was not significant $(\mathrm{P}>0.05)$ in analysis of variance, so heritability was not calculated.

Table 6. - Pearson and genetic correlations among tree height, stem diameter at breast height (Dbh) and wood basic density at 39 months for Calycophyllum spruceanum. Correlations are given for all trees across zones, and separately for trees in the lower, middle and upper zones of the watershed. The significance (for Pearson r) or standard error (for genetic correlation) is given in parentheses, followed by the number of trees involved in the calculation. ${ }^{a}$

A. Pearson correlations

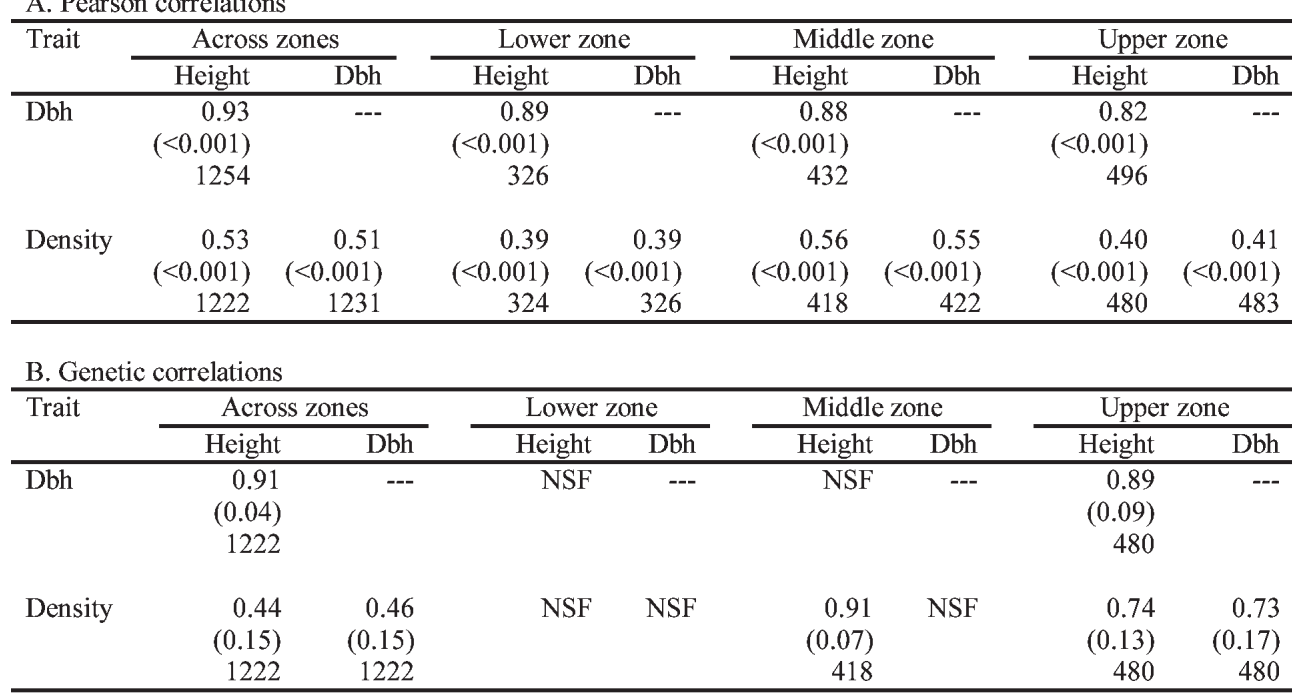

a NSF = Family within provenance was not significant $(\mathrm{P}>0.05)$ for one or both variables in analysis of variance, so genetic correlation was not calculated. 
highest in the upper zone and lowest in the lower zone. In the analysis across zones, $h_{i}^{2}$ of both height and diameter increased slightly from 16 to 28 months and then leveled off. Time trends were not consistent, however, in the three zones.

Wood density had higher $h_{i}^{2}$ than Dbh at 39 months. The $h_{i}^{2}$ was higher in the middle and upper zones than in the lower zone, but the difference was not statistically significant based on the standards errors.

The phenotypic (Pearson) and genetic correlations indicated that larger trees (i.e., trees with greater height and Dbh) tended to have denser wood (Table 6). The standard errors of genetic correlations were generally less than $33 \%$ of the estimated correlation.

\section{Discussion}

\section{Variation in tree growth}

Mean growth of Calycophyllum spruceanum at 16 and 39 months was similar to values observed at 18 and 42 months in another test of this species conducted in the same watershed, but with a different set of provenances (Sotelo Montes et al., 2003; Weber and Sotelo Montes, 2005). Also, its growth was similar to other tropical hardwoods of comparable age in plantations in Latin America [e.g. Alnus acuminata Kunth. in Costa Rica (CoRnelius et al., 1996); Carapa guianensis Aubl. (BAUCH and DÜNISCH, 2000) in Brazil; Sterculia apetala (Jacq.) Karst in Colombia (DvorAK et al., 1998)].

Results confirm that there is a potential to increase plantation yield by selecting fast-growing families and provenances of $C$. spruceanum at an early age. Provenances and especially families within provenances accounted for significant variation in tree height and stem diameter (10 $\mathrm{cm}$ above ground) at 16, 28 and 39 months, and in diameter at breast height (Dbh) at 39 months in the analysis across planting zones. Moreover, provenance means for height and diameter (but not Dbh), and family means for height, diameter and Dbh were relatively stable across zones. Significant variation in tree growth due to provenances and/or families has also been detected at early ages in several tropical hardwoods tested in Latin America [e.g., Alnus acuminata Kunth. (CoRNeliUs et al., 1996); Bombacopsis quinata (Jacq.) Dugand (HodGe et al., 2002); Gmelina arborea Roxb. (Osorio, 2004); Grevillea robusta Cunn. (SHIMIzU et al., 2002); Guazuma crinita Mart. (Rochon, 2004); Vochysia guatemalensis Sm., J.D. in Costa Rica (CoRNELIUS and MESÉN, 1997)].

These results are noteworthy because the provenances/families were sampled from a small region in one watershed; replication size was relatively large, which probably increased the environmental variation within the replications; and farmers' erratic weeding practices produced considerable variation within and among replications. The latter two factors would tend to increase the residual variation and the family by replication interaction, making it more difficult to detect statistically significant variation due to families. The large residual variation is probably the major reason why variation due to families was not significant for diameter (at $10 \mathrm{~cm}$ above ground) and Dbh in all planting zones. In addition, estimates for mean Dbh of families and most provenances were based on small sample sizes, especially within zones. This produced large standard errors, which also made it more difficult to detect statistically significant variation due to provenances and families.

Planting zones generally produced larger differences in tree growth, compared with families and provenances. For example, the range in mean height, diameter (10 $\mathrm{cm}$ above ground) and Dbh, respectively, at 39 months was $5.35 \mathrm{~m}, 6.53 \mathrm{~cm}$ and $4.37 \mathrm{~cm}$ among planting zones; $4.09 \mathrm{~m}, 5.23 \mathrm{~cm}$ and $6.30 \mathrm{~cm}$ among families; and only $0.70 \mathrm{~m}, 1.08 \mathrm{~cm}$ and $0.69 \mathrm{~cm}$ among provenances. Therefore, the greatest gains in plantation yield can be realized first by selecting the best planting zone, and then selecting the fastest growing and best adapted families for that zone. Although provenances did not account for much variation, additional gain could be achieved by selecting the best provenances.

The coefficients of variation indicated that there was relatively more variation in growth among trees in the planting zones with lower rainfall and less fertile soils (lower and middle zones) than in the zone with the highest rainfall and most fertile soils (upper zone). This could reflect two interacting factors (WEBER and SoTELO MonTES, 2005). First, farmers' erratic weeding practices undoubtedly produced considerable spatial and temporal variation in soil moisture, temperature and fertility within the replications. One would expect this microenvironmental variation to produce greater differences in growth among neighboring trees in a zone of low rainfall and infertile soils than in a zone of high rainfall and fertile soils. Second, if there is phenotypic variation in drought-tolerance mechanisms such as leaf abscission, one would expect greater variation to be expressed among trees planted in the drier planting zones. In the upper zone, partial leaf abscission in the upper canopy was rarely observed among trees in the replications during the dry season. But in the lower and middle zones, neighboring trees within the replications varied from partial to complete leaf abscission during the dry season. Since leaf abscission reduces the photosynthetic surface, variation in leaf abscission among neighboring trees could produce substantial variation in growth rates (e.g., DvorAK et al., 1998).

\section{Variation in basic density of juvenile wood}

Mean basic density of $C$. spruceanum wood at 39 months (581 kg/m $\mathrm{m}^{3}$, measured at $1.3 \mathrm{~m}$ above ground) was slightly higher than the value at 32 months observed in another test of this species $\left(563 \mathrm{~kg} / \mathrm{m}^{3}\right.$, measured from 35 to $65 \mathrm{~cm}$ above ground; WEBER and SOTELO Montes, 2005). The coefficient of variation (8\% among all trees) was slightly greater than the values reported (around 5\%) for other tropical hardwoods at 5-9 years of age in plantations (MIRANDA et al., 2001; RAYMOND and MUNERI, 2001; SANTOS et al., 2004).

Like the growth traits, there was significant variation in basic density due to provenances and especially families within provenances, and means for both provenances and families were relatively stable across zones. As mentioned above for Dbh, this is noteworthy because 
means for families and most provenances were estimated from a small number of trees, especially within zones, and this resulted in large standard errors that made it difficult to detect statistically significant variation due to provenances and families. Families accounted for much more variation than did provenances: the range in mean density was $148 \mathrm{~kg} / \mathrm{m}^{3}$ among families, but only $33 \mathrm{~kg} / \mathrm{m}^{3}$ among provenances. Therefore, greater gains in density could be obtained by selecting the best families rather than the best provenances. Nevertheless, average wood density could also be improved by selecting the best provenances.

The significant variation observed in the present study is interesting considering that variation due to provenances was not significant for wood density in another test of $C$. spruceanum at 32 months (WEBER and Sotelo Montes, 2005). The lack of significance in the earlier study was probably due to the fact that provenances originated from a region closer to the equator and with relatively homogenous climatic conditions.

There has been little research on genetic variation in wood density at an early age in tropical hardwood plantations. KHASA et al. (1995) reported significant differences in density at 21 months among provenances of Racosperma auriculiformis Cunn. ex. Benth. and $R$. mangium Willd. that were sampled from a broad range of environments in Australia and tested in Zaire. Other reports of significant variation due to provenances and/or families are based on older trees [e.g., Eucalyptus dunnii Maiden at $6 \frac{1}{2}$ years (ARNOLD et al., 2004); E. globulus Labill. at 9 years (MIRANDA et al., 2001); $E$. grandis (Hill ex Maiden) at 8 years (SANTOs et al., 2004); and Sterculia apetala (Jacq.) Karst at 10 years (DVORAK et al., 1998)].

In contrast to the growth traits, wood density did not differ significantly among the three planting zones in the present study. Weber and Sotelo Montes (2005) reported similar results for density in the lower stem in another provenance test of $C$. spruceanum established in the same planting zones. Apparently the environmental differences among zones were not large enough to produce a significant difference in density. Nevertheless, in the present study mean density was lowest in the zone of slowest tree growth (lower zone) and the range in mean density among the zones was relatively large $\left(47 \mathrm{~kg} / \mathrm{m}^{3}\right)$. Therefore the environmental conditions of different planting zones should be assessed before deciding to establish plantations in the zones.

\section{Heritability of tree growth and basic density of juvenile wood}

Estimates of individual tree heritability $\left(h_{i}^{2}\right)$ for growth traits of $C$. spruceanum were within the range of values reported for other tropical hardwoods at an early age (e.g., Cornelius et al., 1996; Greaves et al., 1997; SHIMIZU et al., 2002). The estimated $h_{i}^{2}$ was slightly higher for tree height than stem diameter at $10 \mathrm{~cm}$ above ground: $h_{i}^{2}$ across zones, averaged over ages, was 0.25 for height and 0.19 for diameter (Table 5). A similar result was reported for other tropical hardwoods (PINYOPUSARERK et al., 1996; HODGE et al., 2002).
In general, estimates of $h_{i}^{2}$ for both height and diameter suggest that selection of trees at 16 months would be about as efficient as selection at 28 or 39 months. For example, in the analysis across zones, $h_{i}^{2}$ for both height and diameter did not change significantly from 16 to 39 months. The $h_{i}^{2}$ for growth of Sterculia apetala (Jacq.) also did not change significantly from 3 to 8 years of age (DvoraK et al., 1998).

The $h_{i}^{2}$ for height and diameter were highest in the planting zone where growth rate was highest and lowest in the zone where growth rate was lowest (upper and lower zones, respectively). This is consistent with CAMPBELL and SoRENSEN's (1978) hypothesis that the expression of genetic variation in growth traits will be lower in test environments where trees grow slowly compared with environments where trees grow more rapidly. Similar results were reported for Eucalyptus spp. (MACDONALD et al., 1997; GiNWAL et al., 2004).

As expected, wood density had a higher $h_{i}^{2}$ than diameter at breast height (Dbh) at 39 months. Standard errors were relatively large, especially within zones, due to the small number of trees per family. As far as we know, $h_{i}^{2}$ of wood density has not been assessed at a very early age in other tropical hardwoods, but these results are consistent with studies of tropical hardwoods evaluated at older ages (e.g., WEI and BoRRALHO, 1997; RAYMOND, 2002; ARNOLD et al., 2004), and with many temperate zone tree species (ZOBEL and JETT, 1995).

\section{Phenotypic and genetic correlations between tree growth and basic density of juvenile wood}

Phenotypic and genetic correlations may differ in magnitude and even in sign among test environments and populations of the same species (FALCONER and MACKAY, 1996), and due to silvicultural manipulation (ZHANG, 1995). In general, the diffuse-porous hardwoods show little or no relationship between tree growth and wood density (ZOBEL and JETT, 1995). Most studies have looked at the relationship between density and radial growth or ring width rather than the relationship with height growth (ZHANG, 1995).

The relationship between growth rate and wood density in the hardwoods is controversial. For example, among young trees of Eucalyptus nitens in Australia, phenotypic correlations between density and growth (tree height, stem diameter) were not significant, but the genetic correlation between density and stem diameter (but not tree height) was negative and significant (GREAVES et al., 1997). For Eucalyptus globulus and $E$. nitens, the correlations were generally very small and the sign of the coefficient varied across sites, indicating no systematic relationships of density with tree size (RAYMOND and MUNERI, 2001).

In the present study, phenotypic correlations between tree growth and wood density at breast height were positive and relatively strong in all planting zones at 39 months. However, in another test of this species, carried out in the same watershed but with provenances from different watersheds (WeBER and Sotelo Montes, 2005), the phenotypic correlation between stem diameter and density in the lower stem varied in magnitude and sign among planting zones at 32 months. In that 
study, the variance/covariance structure among traits in the "foreign" seed sources was apparently strongly affected by the environmental differences among the planting zones. In other words, the genotypes did not respond in the same way to the environmental differences (FALCONER and MACKAY, 1996). In the present study, genotypes of the "local" seed sources tended to respond in the same way to the environmental differences among planting zones. The difference in results appears to reflect the combined effects of different genetic material ("foreign" versus "local" seed sources) and their potential interactions with different environmental conditions, but this hypothesis needs to be tested.

Genetic correlations between tree growth and wood density were positive in the middle and upper zones. The genetic correlation was not calculated in the lower zone, where tree growth was slowest, because variation in tree growth due to families was not significant in the analysis of variance. This is consistent with CAMPBELL and SorEnsen's (1978) hypothesis mentioned earlier. Based on the genetic correlation, selection of faster growing trees should favor an increase in wood density in planting zones where trees grow relatively rapidly (like the middle and upper zones), and have little or no effect on density in zones where trees grow slowly (like the lower zone) for reasons explained in the following paragraph. However, estimates are needed from other tree populations and test environments in order to make a general conclusion about the genetic correlation between growth and density in this species. Standard errors were reasonably small, even though the genetic correlations were based on a small number of trees per family (especially for Dbh and wood density). Nevertheless, larger numbers of trees per family should be used in future studies.

Since there is a positive genetic correlation between wood density and tree growth of C. spruceanum, and density is considered as the most important predictor of wood properties (PANshin and DE ZEeuw, 1980), one would expect a correlation between tree growth and other wood properties in this species. Results from another study in the same provenance/progeny test at 39 months indicated that selecting faster-growing trees and/or trees with denser wood of C. spruceanum would have a positive effect on some mechanical properties (Sotelo Montes et al., unpublished data).

A positive genetic correlation between tree growth and wood density at breast height could be explained in terms of the mechanical design of trees. MOsBRUGGER (1990) notes that the base of the tree has the highest bending stress and this stress can be reduced by increasing the strength of supporting tissue at the base of the tree. Strength could be increased by producing denser wood, which has a greater modulus of elasticity (NIKLAS, 1997). This hypothesis is consistent with results reported for other tropical, hardwood pioneer species (WIEMANN and WILLIAMSON, 1989; WoODCOCK and SHIER, 2002).

Data are not available to estimate age-age correlations between tree growth and wood density in $C$. spruceanum. A study of age-age correlations that consid- ers the rotation ages for construction poles (minimum of 2 to 3 years) and sawn timber ( 15 to 20 years) would be very useful. However, studies on other hardwood species indicate that early selection for density and tree growth should be possible (DvORAK et al., 1998; HodGe et al., 2002).

\section{Conclusions}

This study demonstrates that there is considerable genetic variation in tree growth and basic wood density of C. spruceanum at an early age. A greater proportion of this variation occurs within provenances rather than among provenances. The positive genetic correlation between growth and density offers the opportunity to select faster growing trees with denser wood, and this would be more effective in zones where trees grow relatively rapidly. Estimates of $h_{i}^{2}$ for the traits assessed in this study are similar to those reported for other tropical hardwoods. Based on estimates of $h_{i}^{2}$ and genetic correlations, we recommend that tree improvement programs should use both tree growth and wood density as selection criteria for this species at an early age. For example, tree breeders could first select the fastest growing provenances based on $\mathrm{Dbh}$, and then select the families that have the highest wood density within these provenances. Due to the lower performance in tree growth in the planting zone with low rainfall and infertile soils, plantations in similar environments should be avoided. Relationships between tree growth, wood density and other juvenile-wood properties should be investigated: these studies are underway for C. spruceanum, and will allow us to make some general recommendations about planting zones for different wood products of this species. In addition, research should be conducted on changes in genetic correlations between tree growth and wood properties over time, age-age correlations for growth and wood traits, and early-selection efficiency for this species.

\section{Acknowledgements}

The first author acknowledges grants and support for research expenses provided by the Organization of American States, Laval University, the Canadian Forest Service, and the World Agroforestry Centre (ICRAF). We are grateful to the collaborating staff from Laval University, the Canadian Forest Service and ICRAF; the farmers in Peru; and the anonymous reviewers for their comments and recommendations. The provenance/family test was supported by grants to ICRAF from the Interamerican Development Bank, the Government of Spain, the Governments of Netherlands and Norway as part of the CGIAR Global Initiative for Alternatives to Slash and Burn, the Department for International Development of the United Kingdom, and Winrock International as part of the USAID Alternative Development Program.

\section{References}

ARNold, R. J., I. G. Johnson and J. V. Owen (2004): Genetic variation in growth, stem straightness and wood properties of Eucalyptus dunnii trials in northern New South Wales. Forest Genetics 11: 1-12. 
ASTM (1997): Standard test methods for specific gravity of wood and wood-base materials. ASTM D2395-93. In: Annual book of ASTM Standards 4.10. pp. 348-355. American Society for Testing and Materials, Philadelphia.

BAUCH, J. and O. DÜNISCH (2000): Comparison of growth dynamics and wood characteristics of plantation-grown and primary forest Carapa guianensis in Central Amazonia. IAWA Journal 21: 321-333.

BAWA, K. S., P. S. AshTON and S. M. Nor (1990): Reproductive ecology of tropical forest plants: management issues, pp. 3-13. In: Reproductive ecology of tropical forest plants, edited by K. S. BAWA and M. HADLEY, UNESCO, Paris.

BECKER, W. A. (1984): Manual of Quantitative Genetics, $4^{\text {th }}$ Edition. Academic Enterprises, Pullman.

CAMpbell, R. K. and F. C. Sorensen (1978): Effect of test environment on expression of clines and on delimitation of seed zones in Douglas-fir. Theoretical and Applied Genetics 51: 233-246.

Cornelius, J., F. Mesén, E. Corea and M. Henson (1996): Variation in growth and form of Alnus acuminata Kunth. grown in Costa Rica. Silvae Genetica 45: 24-30.

Cornelius, J. P. and J. F. Mesén (1997): Provenance and family variation in growth rate, stem straightness, and foliar mineral concentration in Vochysia guatemalensis. Canadian Journal of Forest Research 27: 1103-1109.

Dvorak, W. S, H. Uruena, L. A. Moreno and H. Goforth (1998): Provenance and family variation in Sterculia apetala in Colombia. Forest Ecology and Management 111: $127-135$.

FALCONER, D. S. and T. F. C. MACKAY (1996): Introduction to Quantitative Genetics. Addison Wesley Longman Limited, Edinburgh.

Ginwal, H. S., P. Kumar, V. K. Sharma, A. K. Mandal and C. E. HARWOOD (2004): Genetic variability and early growth performance of Eucalyptus tereticornis Sm. in provenance cum progeny trials in India. Silvae Genetica 53: $148-153$.

Greaves, B. L., N. M. G. Borralho, C. A. Raymond, R. Evans and PH. Whiteman (1997): Age-age correlations in, and relationships between basic density and growth in Eucalyptus nitens. Silvae Genetica 46: 264-270.

Hodge, G. R., W. S. Dvorak, H. Urueña and L. Rosales (2002): Growth, provenance effects and genetic variation of Bombacopsis quinata in field tests in Venezuela and Colombia. Forest Ecology and Management 158: 273-289.

KeEnan, F. J. and M. TEJadA (1984): Tropical timber for building materials in the Andean Group countries of South America. International Development Research Centre, Ottawa.

Khasa, P. D., P. Li, G. Vallée, S. Magnussen and J. BousQUET (1995): Early evaluation of Racosperma auriculiforme and $R$. mangium provenance trials on four sites in Zaire. Forest Ecology and Management 78: 99-113.

LinARES, C., E. Meneses and J. DiAZ (1992): Monografía sobre capirona: Calycophyllum spruceanum. Proyecto Forestal ITTO PD 37/88 Utilización industrial de nuevas especies forestales en el Perú. Cámara Nacional Forestal, Dirección General de Forestal y Fauna, Lima.

MacDonald, A. C., N. M. G. Borralho and B. M. Potts (1997): Genetic variation for growth and wood density in Eucalyptus globulus ssp. globulus in Tasmania (Australia). Silvae Genetica 46: 236-241.
Miranda, I., M. H. Almeida and H. Pereira (2001): Provenance and site variation of wood density in Eucalyptus globulus Labill. at harvest age and its relation to a nondestructive early assessment. Forest Ecology and Management 149: 235-240.

Morgenstern, E. K. (1996): Geographic Variation in Forest Trees - Genetic Basis and Application of Knowledge in Silviculture. University of British Columbia Press, Vancouver.

Mosbrugger, V. (1990): The Tree Habit in Land Plants. Lecture Notes in Earth Sciences, edited by S. BHATtacharji, G. M. Friedman, H. J. Neugebauer and A. SEILACHER. Springer-Verlag, Berlin.

NIKLAS, K. J. (1997): Size- and age-dependent variation in the properties of sap- and heartwood in Black Locust (Robinia pseudoacacia L.). Annals of Botany 79: 473-478.

OsorIo, L. F. (2004): Provenance results of Gmelina arborea in southwest Colombia at three years of age. New Forests 28: 179-185.

Panshin, A. J. and C. DE ZeEuw (1980): Textbook of Wood Technology. McGraw-Hill Book Company, New York.

Pinyopusarerk, K., J. C. Doran, E. R. Williams and P. WASUWANICH (1996): Variation in growth of Eucalyptus camaldulensis provenances in Thailand. Forest Ecology and Management 87: 63-73.

RAYMOND, C. A. and A. MunERI (2001): Nondestructive sampling of Eucalyptus globulus and E. nitens for wood properties. I. Basic density. Wood Science and Technology 35: 27-39.

RAYMOND, C. A. (2002): Genetics of Eucalyptus wood properties. Annals of Forest Science 59: 525-531.

RochON, C. (2004): Croissance et densité du bois de sept provenances de Guazuma crinita Mart. dans le bassin de l'Amazonie péruvienne. M.S. thesis, Département des Sciences du Bois et de la Forêt, Université Laval, Québec.

Russell, J. R., J. C. Weber, A. Booth, W. Powell, C. Sotelo Montes and I. K. Dawson (1999): Genetic variation of riverine populations of Calycophyllum spruceanum in the Peruvian Amazon Basin, revealed by AFLP analysis. Molecular Ecology 8: 199-204.

SAntos, P. E. T., I. O. Geraldi and J. N. Garcia (2004): Estimates of genetic parameters of wood traits for sawn timber production in Eucalyptus grandis. Genetics and Molecular Biology 27: 567-573.

SAS InSTITUTE INC. (1999): SAS/STAT Users' Guide, Version 8. SAS Institute Inc., Cary.

SEARS, R. R. (2003): New forestry on the floodplain: the ecology and management of Calycophyllum spruceanum (Rubiaceae) on the Amazon landscape. Ph.D. dissertation, Graduate School of Arts and Sciences, Columbia University, Ithaca.

Shimizu, J. Y., L. A. Spence, E. G. Martins and A. J. DE ARAUJO (2002): Genetic and phenotypic variations in early growth performances of grevillea trees for use in agroforestry systems. International Forestry Review 4: $128-132$.

Sotelo Montes, C. and J. C. Weber (1997): Priorización de especies arbóreas para sistemas agroforestales en la selva baja del Perú. Agroforestería en las Américas 4: 12-17.

Sotelo Montes, C., H. Vidaurre and J. C. Weber (2003): Variation in stem-growth and branch-wood traits among provenances of Calycophyllum spruceanum Benth. from the Peruvian Amazon. New Forests 26: $1-16$. 
Steel, R., J. TorRIE and D. Dickey (1997): Principles and Procedures of Statistics - a Biometrical Approach, $3^{\text {rd }}$ Edition. McGraw-Hill Series in Probability and Statistics, Boston.

TOLEDO, E. and C. RINCóN (1996): Utilización industrial de nuevas especies forestales en el Perú. Cámara Nacional Forestal, Instituto Nacional de Recursos Naturales, Organización Internacional de las Maderas Tropicales, Lima.

Weber, J. C., C. Sotelo Montes, H. Vidaurre, I. K. DaWson and A. J. Simons (2001): Participatory domestication of agroforestry trees: an example from the Peruvian Amazon. Development in Practice 11: 425-433.

WeBer, J. C. and C. Sotelo Montes (2005): Variation and correlations among stem growth and wood traits of Calycophyllum spruceanum Benth. from the Peruvian Amazon. Silvae Genetica 54: 31-41.
WeI, X. and N. M. G. Borralho (1997): Genetic control of wood basic density and bark thickness and their relationships with growth traits of Eucalyptus urophylla in south east China. Silvae Genetica 46: 245-250.

Wiemann, M. C. and G. B. Williamson (1989): Radial gradients in the specific gravity of wood in some tropical and temperate trees. Forest Science 35: 197-210.

Woodcock, D. W. and A. D. SHIER (2002): Wood specific gravity and its radial variations: the many ways to make a tree. Trees 16: 437-443.

ZHANG, S. Y. (1995): Effect of growth rate on wood specific gravity and selected mechanical properties in individual species from distinct wood categories. Wood Science and Technology 29: 451-465.

Zobel, B. J. and J. B. JeTt (1995): Genetics of Wood Production. Springer-Verlag, Berlin.

Zobel, B. J. and J. R. SpRAgue (1998): Juvenile Wood in Forest Trees. Springer-Verlag, Berlin.

\title{
Construction of Microsatellite Linkage Maps for Corymbia
}

\author{
By M. ShePherD ${ }^{1), 3)}$, S. KASEM ${ }^{1)}$, D. LeE $^{2)}$ and R. HenRY ${ }^{1), 3)}$
}

(Received 14 $4^{\text {th }}$ March 2006)

\begin{abstract}
The genus Corymbia is closely related to the genus Eucalyptus, and like Eucalyptus contains tree species that are important for sub-tropical forestry. Corymbia's close relationship with Eucalyptus suggests genetic studies in Corymbia should benefit from transfer of genetic information from its more intensively studied relatives. Here we report a genetic map for Corymbia spp. based on microsatellite markers identified de novo in Corymbia sp or transferred from Eucalyptus. A framework consensus map was generated from an outbred $\mathrm{F}_{\text {. }}$ population $(\mathrm{n}=90)$ created by crossing two unrelated Corymbia torelliana x C. citriodora subsp. variegata $\mathrm{F}_{1}$ trees. The map had a total length of $367 \mathrm{cM}$ (Kosambi) and was composed of 46 microsatellite markers distributed across 13 linkage groups (LOD 3). A high proportion of Eucalyptus microsatellites (90\%) transferred to Corymbia. Comparative analysis between the Corymbia map and a published Eucalyptus map identified eight homeologous linkage groups in Corymbia with 13 markers mapping on one or both maps. Further comparative analysis was limited by low power to detect linkage due to low genome coverage in Corymbia, however, there was no convincing evidence for chromosomal structural

\footnotetext{
1) Centre for Plant Conservation Genetics, Southern Cross University, PO Box 157, Lismore, NSW 2480, Australia. E-mail: shepher@scu.edu.au

2) Department of Primary Industries and Fisheries, Horticulture and Forestry Science, LB 16 Fraser Road, Gympie, QLD 4570, Australia.

3) Cooperative Research Centre for Sustainable Production Forestry, Southern Cross University, PO Box 157, Lismore,
} NSW 2480, Australia.
\end{abstract}

differences because instances of non-synteny were associated with large distances on the Eucalyptus map. Segregation distortion was primarily restricted to a single linkage group and due to a deficit of hybrid genotypes, suggesting that hybrid inviability was one factor shaping the genetic composition of the $\mathrm{F}_{2}$ population in this inter-subgeneric hybrid. The conservation of microsatellite loci and synteny between Corymbia and Eucalyptus suggests there will be substantial value in exchanging information between the two groups.

Key words: Corymbia torelliana; Corymbia citriodora subsp. variegata; genetic map; hybrid inviability; genetic marker; tree improvement; marker-aided selection.

\section{Introduction}

The development of genetic maps and a comparative analysis of maps amongst related plant groups has provided new insights into genome structure, organisation and evolution, with implications for plant improvement, gene pool conservation and management (NEWBURY and PAterson, 2003). Comparative studies are particularly valuable for commercial taxa which are resource poor in genetic information (eg. DNA markers or DNA sequence data) but where they have near relatives that are resource rich (BROwn et al., 2001). This situation exists for the genera Eucalyptus and Corymbia; most eucalypts of commercial importance belong to the genus Eucalyptus, the great majority of gene sequence and marker information is derived from a few Eucalyptus species, $E$. grandis, $E$. urophylla and $E$. globulus. The genus Corymbia has 113 species in 7 sections and includes 